\title{
White Collar Crime and Informal Social Control: The Case of "Crisis Responders" in the Swedish Banking and Finance Sector
}

\author{
Oskar Engdahl \\ Department of Sociology, University of Gothenburg, Gothenburg, Sweden. \\ Email: oskar.engdahl@sociology.gu.se \\ Received February $16^{\text {st }}, 2011$; revised March $15^{\text {th }}, 2011$; accepted March $18^{\text {th }}, 2011$.
}

\begin{abstract}
Drawing upon case studies on the type of white-collar offenders frequently called "crisis responders", this article critically examines Sampson and Laub's general theory on informal social control. In the article, this theory is for the first time confronted with data not used in its development and prior testing. Based on the evidence, the theory retains its validity for the white-collar offenders considered, insofar as their crime was closely connected to a perceived threat of identity loss, distrust in social support obtainable from others, and lack of supervision and monitoring at workplace. At the same time, the argument is made that the notion of interdependence relied upon in this theory needs to be developed more fully if it is to take into account the kind of dependency relations tying these particular offenders to their environment.
\end{abstract}

Keywords: Informal Social Control; White-collar Crime; Crisis Responders

\section{Introduction}

The theory of informal social control as advanced in the work of Robert J. Sampson and John H. Laub has attracted much attention in the recent years, being today proposed as a general theory of crime. Parts of this work, which remains under development, have been published in book format (Sampson \& Laub, 1993; Laub \& Sampson, 2003), in anthologies (Sampson \& Laub, 2005b; Laub et al., 2006), and in leading periodicals (Sampson \& Laub 1990; 2003; 2005a; Laub \& Sampson, 1993; Laub et al., 1998). The theses put forth in these writings have become widely debated and critically scrutinized by other researchers in the field (see, e.g., Uggen, 2000; Giordano et al., 2002, 2007; Ezell \& Cohen, 2005; Bottoms, 2006; Thompson \& Petrovic, 2009), and are featured prominently in criminology textbooks and both introductory and advanced level course materials. ${ }^{1}$ Through all these channels Sampson and Laub manage to make a dynamic and influential contribution to general theory building in the discipline.

In advancing their work, Sampson and Laub have relied on empirical data typical of criminological studies more generally. The evidence they have drawn upon relates mostly to crime of violence, theft, and drug-related crime, all committed by highrate offenders in socially disadvantaged communities. This is primarily also the type of data used in the evaluation and testing of Sampson and Laub's theses. No studies deviating from essentially the same empirical foundation have been published to date. In view of the influence and the global aspirations of Sampson and Laub's theory, this state of affairs can only be deemed less than satisfactory.

As a corrective, therefore, this article looks at novel evidence derived from qualitative analysis of white-collar offenders, confronting the theory with its implications. More precisely, the

${ }^{1}$ See, e.g., Paternoster \& Bachman, 2000; Piquero and Mazerolle, 2001; Bernard et al., 2010: 316-319; Cullen et al., 2005; Lilly et al., 2007; Williams III and McShane, 2009: 209-212. study reported below tackles white-collar crime committed in the course of normal business activities within the Swedish banking and finance sector by individuals classifiable as "crisis responders" (Waring et al., 1995; Weisburd et al., 2001). In broader research, crisis responders form a frequently noted but theoretically less elaborated category of criminals, with characteristics quite different from those marking the materials used in the research tradition forming around Sampson and Laub. The purpose of this article is therefore twofold: To contribute to the theoretical reflection on the social circumstances making the crime of the crisis responders more likely, and to examine whether Sampson and Laub's theory on informal social control yields useful tools for improving our understanding of whitecollar crime.

In what follows, I will first provide an overview of Sampson and Laub's thoughts on informal social control. The discussion is extended to the claims and empirical support of their theory as well. Next, the empirical material relied upon in previous studies is reviewed, along with prior research on crisis responders. Thereafter the findings from my own research are presented in three separate sections, corresponding to three central elements of Sampson and Laub's theory: interdependence and social capital, supervision and monitoring, and situated choice and identity transformations. The main observations concerning the crime of crisis responders are given together with concrete examples illustrating them and then juxtaposed with Sampson and Laub's own conclusions. Lastly, the major conclusions from this discussion are summarized along with its implications for further research.

\section{Sampson and Laub on Informal Social Control}

Sampson and Laub base their understanding of why people begin, alter, and end their criminal careers on the fundamental assumption of classical social control theory according to which delinquency or crime is more likely to occur when an individ- 
ual's bond to society is weak, broken, or attenuated. More specifically, the point Sampson and Laub make is that absence of informal social control associated with interpersonal relations and attachment to social institutions (family, education, labor market, etc.) causes the kind of obligations, emotional ties, and stakes in conformity to dissolve that otherwise impose significant costs for translating criminal propensities into action, inhibiting criminal behavior in an individual. In addition, informal social control also affects opportunities for engaging in crime through its role as a supervision and monitoring mechanism.

Drawing from their own original research and a broad survey of work already carried out in the field, Sampson and Laub (1993) have been able to narrow down on a set of specific factors they see as having significance in this respect. In especial they point out the importance of parenting styles and emotional attachment to parents in childhood, peers and schools attachment in adolescence, and marital stability and employment in adulthood. Despite how disparate these phenomena may seem, maintain Sampson and Laub, essentially they are but so many manifestations of informal social control impinging on an individual throughout life's different phases. Informal social control is therefore best understood as age-graded in its effects, explaining the onset, continuity, variation in, and desistance of criminality by the same general process.

The hallmark of this theory is precisely the notion that informal social control is age-graded and shapes the propensity of individuals to engage in crime throughout the life course. And it is also here that Sampson and Laub's most original contribution lies, both theoretically and in terms of their empirical work. In their investigations, they have gone on to demonstrate how crime frequency varies in the course of an individual life cycle according to the strengthening or weakening of social bonds, regardless of the person's life phase. They have, for instance, shown that, for the same individuals, there is a tendency to commit fewer crimes after getting married and becoming employed, compared to when they were single and without jobs (Sampson \& Laub, 2003), and that even high-rate chronic offenders burdened with significant childhood and adolescence risk factors desist from crime after gaining steady employment, marrying, or entering into military service in adult life (Laub \& Sampson, 2003; Sampson \& Laub, 2003). On this account the authors have found reason to stress that "there are important variations in adult criminal trajectories that cannot be predicted from childhood, contra the policy world and much yearning among criminologists" (Sampson \& Laub, 2005b: 175; see also Sampson \& Laub, 2003: 588).

Sampson and Laub take a particular interest in how salient life events in adulthood can strengthen the social bond and function as "turning points" for persistent offenders, leading them to forgo their life in crime. Such critical junctures may occur when social circumstances cause individuals to be exposed as it were from the outside to social control and routine activities that impose a structure on their everyday life, while in a life situation that makes their acceptance of or positive response to this exposure possible so to speak from the inside. Here the question may be of starting a family or taking on a job, both of which tend to promote an increasing sense of responsibility and expose the alternative of continuing with criminal activities as something irrelevant or outright unacceptable. Such changes become all the more consequential in their effect when the new circumstances also bring separation from the criminal circles and problems that led the person on a course of criminal conduct to begin with and then kept her or him there (the so-called knife-off effect). Sampson and Laub emphasize that this often takes place in a multi-stage process, in which the final outcome-termination of a criminal career was not nearly always something consciously chosen at the outset. As Laub and Sampson (2003: 278f.) themselves put it, "many men made a commitment to go straight without even realizing it. Before they knew it, they had invested so much in a marriage or a job that they did not want to risk losing their investment." With this, the authors want to draw the attention to the interaction between structure and agency, stressing that the choices people make are always situated: we choose to exploit or forgo an opportunity insofar as the decision to do so is likely to bring us something of value, based on past experience and the present situation. It may therefore be that the criminal lifestyle is maintained because it is perceived as something "attractive, exciting, and seductive," offering an opportunity to "articulate resistance to authority" (Laub \& Sampson, 2003: 164-165, 179-186).

Sampson and Laub do, however, point out that social ties can also have the opposite effect if they are felt to be too restrictive. For this reason they stress the importance of interdependence in the social bond, which, in the authors' own account, distinguishes their approach from those of others (Sampson \& Laub, 1993: 18, 21; Laub \& Sampson 1993: 311; 2003: 41f.). Interdependence owes its centrality to the fact that through it both parties gain something positive out of the relationship, which they then do not want to risk by resorting to criminal activities. In this way, social ties reduce the likelihood of crime being committed, serving as they do both a control and a support function that individuals can make use of during different stages of life. To put it in more precise terms, interdependent relations function as social capital, representing "social and psychological resources that individuals can draw on as they move through life transitions that traverse large trajectories" (Sampson \& Laub, 1993: 18f.; Laub et al., 2006: 315). With reference to Coleman (1990) Sampson and Laub understand social capital as an "investment process" linked to concrete and ongoing social relations embedded in institutions like family, school and work where closure ("connectedness") of networks among people are of importance (Laub \& Sampson, 1993: 310-311; 2003: 41f.; Sampson \& Laub, 1993: 18). Sampson and Laub emphasize that social capital is formed through the development of ties between parent-child, employer-employee etc. given that interdependent systems of obligations and restraint are created in these relations. The development of social capital is a reciprocal process and, as they state it, "[T]he mere presence of a relationship (e.g., marriage) among adult is not sufficient to produce social capital, and hence, the idea of social capital goes beyond simple structural notions of role change (i.e., married versus not married) to capture the idea of embeddedness" (Laub and Sampson, 1993: 310f.).

\section{White-Collar Crime and Crisis Responders}

Sampson and Laub's theory builds on an impressive inventory of criminological research to date (Sampson \& Laub, 1993), and to develop their work further the authors have in the 
subsequent years conducted an imposing amount of both qualitative and quantitative empirical research. In this effort, Sampson and Laub have even been able to enlist empirical support for their theses from studies carried out more or less independently of their own frame (Horney et al., 1995; Ezell \& Cohen, 2005; Ezell, 2007). Their theory, in a word, rests on a relatively solid empirical foundation, even if critical reactions and calls for further development of some of its elements have hardly been lacking. ${ }^{2}$ The data used by those testing and developing it further has almost without exception been focused on what could be broadly termed "street crime", primarily crime of violence, theft, and drugs, usually committed in socially disadvantaged neighborhoods and communities by "serious" or "high rate" offenders (Horney et al., 1995; Giordano et al., 2002; 2007; Ezell \& Cohen, 2005; Ezell, 2007; Thompson \& Petrovic, 2009). Sampson and Laub's own empirical material is a "textbook case" of this same analytical orientation. Their theory in all its essentials is founded on data comprising 500 male delinquents committed to reform schools in Boston, Massachusetts, during their adolescence, as matched against data on 500 nondelinquents from the same area. This material was originally collected by Sheldon and Eleanor Glueck at the Harvard Law School in the 1930s, '40s and '50s. What Sampson and Laub added to it was a reanalysis and broadening of this data, the latter through additional document collection and interviews with a selection of the now 70-year-old "Glueck boys" covered by the original materials (Laub \& Sampson, 2003). The work the authors completed was nearly heroic in its proportions, yielding a data sample of what is to all accounts the longest known longitudinal study in the field of criminology to date (Laub et al., 2006: 322).

So far, Sampson and Laub's theory has not been critically examined or even discussed in light of research on white-collar offenders. Considering its stated aspirations to generality and its influence in the field, however, the need for confronting it with just such material is nonetheless pressing. In the present article, an attempt at doing so is made through an analysis of cases consisting of a group of offenders from the Swedish banking and finance sector classified as "crisis responders". In sharp contrast to Sampson and Laub's research material crisis responders is white collar offenders who committed their crime in the course of normal business activities and up until getting caught led a regular life in ordered social settings (in terms of education, employment, housing, family status, etc.). All of the crimes committed were directly connected to the offender's perceived personal financial crisis involving her or his family or working life, with the offenders therefore classifiable as "crisis responders" (Waring et al., 1995: 215; Weisburd et al., 2001: 59-64).

Crisis responders are estimated to make up a large part of all convicted white-collar offenders in the commonly used data on white-collar and economic crime (Waring et al., 1995; Weisburd et al., 2001: 218; see also Alalehto, 2003). It is also essentially this same category of offenders that features in the studies by Cressey (1953) and Zeitz (1981) on embezzlement cases. In research on white-collar and occupational crime, too, relatively

${ }^{2}$ As the primary purpose of this article is to examine Sampson and Laub's theory in the light of empirical data not used in its development, such critical contributions are nonetheless omitted from my discussion. For some examples, see instead Warr, 1998; Uggen, 2000; Giordano et al., 2002; 2007, and Simons, et al. 2002. much attention has been paid to crisis responders (Waring et al., 1995; Weisburd et al., 2001: 59-64; 2008: 184; Alalehto, 2003: 23; Leeper-Piquero \& Benson, 2004; Leeper-Piquero \& Weisburd, 2009: 157).

Within research on economic and white collar crime, crisis responders are often highlighted as a category of criminals showing a basically positive attitude towards and in general a tendency to comply with the prevailing laws and regulations. For this reason they prefer to steer clear of criminal solutions, and even when presented with a lucrative opportunity for crime characteristically let pass the chance to take advantage of it. A crisis that threatens something of high value for them may nonetheless provide compelling enough motivation for the crisis responders to embrace illegitimate means if no other alternative seems feasible. Consequently, this category of offenders has also come to be looked upon as representing a type of Mertonian innovators (Waring et al., 1995; Weisburd et al., 2001).

In terms of their own subjective experience of the situation in which they find themselves at the time of the crime, and the immediate circumstances surrounding it, crisis responders have already been relatively well analyzed in the literature, on the descriptive and conceptual levels at least (Cressey, 1953; Waring et al., 1995; Weisburd et al., 2001; 2008). Very little, however, has been said about how the perception of a crisis and the readiness to commit crime evolve and grow decisive in the matrix of the personal relationships and social networks enveloping them. What this means is that it should be possible to develop Sampson and Laub's theory further, in the interest of obtaining an explanatory model more rigorous than the ones currently on offer. In the sections that follow, therefore, I will advance the argument that it is essentially changes in the social bond that trigger the crises and structure the access to (il)legitimate means that then in turn induce crisis responders to commit their crime. First, after some initial remarks about the material and method used for the study, I will examine Sampson and Laub's claim that social relations must be characterized by interdependence and generate social capital if they are to minimize the likelihood of crime. Second, the argument that the inhibitory effect of social ties on crime derives from their function as a mechanism for supervision and monitoring is considered. Lastly, I will discuss how possible changes in identity may bear on the situational conditions inducing individuals to opt for criminal behavior.

\section{Data and Method used in the Current Study}

Throughout the discussion I will be making references to selected cases from my own study by way of illustration and validation. The cases selected are typical for the entire group of crisis responders and therefore useful for their ability to demonstrate and highlight essential characteristics (Yin, 1989: 61; Flyvbjerg, 2006). This manner of proceedings seems appropriate since the aim indeed is to "solve qualitative problems such as finding out what happens, understanding what this leads to, and uncovering the relationships through which different events are connected" (Honigmann, 1982: 84). The cases used in this way are collected from a study involving a total of 74 crime cases. In these cases individuals have been convicted for crimes committed during the years $1990-2010 .^{3}$ The crimes in question 
are mostly embezzlement and breach of trust and, in some cases, theft, fraud and insider trading. Of the full sample $(\mathrm{N}=74)$ the focus in this article is on the cases which could be classified as clear examples of crisis responders $(\mathrm{N}=46)$.

The material was collected through regular contact with crime investigators at police departments, banks, brokage firms and other actors in the branch. The analyzed material mostly consists of what has been uncovered in the investigations conducted by the affected companies and the judical legal systems. This material consists of police interrogations with suspects and witnesses and various documents seized by the police such as records, invoices, contracts, lists of business transactions, e-mail, personal letters and notes and personal investigations. In terms of gender, age, level of income and education, terms of employment, occupational position, employer firm size, workplace location, and type of crime and its monetary value, the distribution among the study participants was fairly balanced.

The collected material has been used to reconstruct the sequence of events in which the criminal acts have been embedded. The material has been treated as "traces" of the committed acts and by analyzing them I have tried to find out what has happened and under which conditions it all has taken place. In this work I have paid particular attention to following the money and assets from the crime. Questions regarding how the money has been taken, from whom it has been taken and how it subsequently has been used have all been of particular importance to answer. How the money has been handled has therefore been a starting point for both the collection of the material and the analysis. Information about the offenders personal experiences as well as their various situational and contextual factors of their crimes have been analyzed in relation to the offenders way of committing the crime. The purpose of this has been to help elucidating the mechanisms and conditions leading to delinquency (Cressey, 1953: 14).

\section{Nonshareable Problems and Loss of Social Capital}

The most conspicuous finding of the group of crisis responders was that in all cases the crime committed had an immediate connection to a personal economic crisis affecting the offender's work or family life whose content and consequences the offender nonetheless attempted to hide from her or his environment. Losses and debts from deals gone sour, negligence and oversight at workplace, and a lifestyle beyond one's means (investments in a new home, vacation trips, cars, designer clothes, gambling, and the like) represented some of the most notable problems in this respect. What was common to all instances is also that the financial crisis brought on as a consequence was closely associated with social problems, evident in the anguish with which the need to disclose the issue to others and seek their help in resolving the matter was met. Fearing the consequences of stigmatization, the offenders had little trust in finding a sympathetic ear in their environment while believing their position in family and/or professional life to be at stake

\footnotetext{
${ }^{3}$ The ambition has been to collect all cases relevant for the area. Due to the fact that cases of this sort are never recorded by official authorities in a way that they are searchable in some kind of register, and because a great deal of those crime committed never are uncovered or handled in a way that they get to public attention there is - of course - a great risk of missing relevant cases (Williams, 2004; 2005).
}

should the problems be revealed.

A good example of this dilemma was a bank manager who, over a period of four years, embezzled money from the branch where she worked, in order to avoid having to tell her husband that she, without the latter's knowledge and consent, had spent the money meant for their shared expenses on other purposes instead. The husband was meticulous in his manner, conscientious in his duties, and spoke often of the importance of paying bills on time. Upon learning that the joint account that was to be used for the expenses of their fashionably located house had been overdrawn due to his wife's falling behind with her own contributions to it, he became extremely irritated. Adding to the husband's aggravation was the circumstance that the bank manager spouse had even been reminded of the matter which, due to worsening interest rates, the rising cost of living, and stagnating salaries, had only become that much more urgent in the prevailing economic climate. For this reason, he had often mentioned the necessity to "tighten the belt" and "live according to one's means." That, however, was precisely where the problem lay. The bank manager had not just been neglectful in making her deposits on schedule, as assumed by her husband: she simply lacked the means to make the transfers expected from her. For despite the husband's admonitions and the tougher economic times, she had convincingly insisted that even now they were able to afford accepting invitations from their friends to join them for vacation trips, and then paid considerably more on them than what the husband had been told. Behind all her actions there was a fear of losing contact with the friends in question should their invitations be declined, which fear was but magnified by the brusque dismissal by which her every suggestion for a more affordable alternative had been met. In addition, the bank manager had spent considerable amounts of money on her wardrobe, something she thought necessary to meet the expectations at her place of work and, as she herself expressed it, to "cheer up" her husband on various occasions.

Soon enough, the bank manager was in arrears with all her payments, having used up her credit limits and overdrawn her accounts. In the end, she had no resources left to continue paying her share of the common expenses in the household budget. The situation grew critical. She and her husband had always trusted each other in economic matters, which trust she now felt she had betrayed. As a result, she became only more and more entangled in problems whose dimensions and type were entirely new to her, while the husband's fits of irritation over her perceived "slackness" became more and more frequent. She felt ashamed of her behavior and began to fear that she would no longer be able to win the sympathy and support of her husband for her betrayal. She also started being afraid of her husband's going "nuts" and "ballistic" if he ever were to find out about her doings. Bowed down by shame and fear, she dared not approach her coworkers or family to confide in them her troubles and feelings. At the age of forty-two, she then committed her first crime in an attempt at embezzlement at her own bank branch.

The bank manager's actions and social situation represent a typical case among those I researched. In my materials, it was without exception always a question of individuals finding themselves enmeshed in problems whose scope and nature they were not used to handling. They felt shame for what they had done, and believed they would be jeopardizing something 
meaningful to them if their problems were to be disclosed to others. In other words, they suffered from what Cressey (1953) characterized as "nonshareable problems," doubting that the mental and social capital that they were accustomed to relying on and that would be needed for finding a legitimate solution to their problems would still be accessible to them. For this reason, they had little trust in their ability to solve their problems in open communication with their environment. Instead, they made use of the opportunities availed them by their work to engineer a solution behind the scenes. Access to other people's money was then utilized to avoid emotionally all too straining and risky encounters, providing an alternative way to solve relational problems when openness and candor were not an option (Engdahl, 2008).

This kind of reasoning stands well in line with Sampson and Laub's thesis that social capital which inhibits criminal intentions is most readily mobilized in relationships characterized by interdependence. Absent that quality, the possibility of having one's voice heard becomes adversely affected. In the case of crisis responders, this may happen as a result of mistakes and shortcomings that have left them unable to live up to the demands and expectations on which the support and influence they had been able to enjoy in their social relations was premised. The understanding of their decitfulness and destroyed social capital finds expression in a sense of discomfort and even outright fear at the thought of talking about one's problems and priorities, not expected to be recognized as legitimate by the environment (Kemper, 1978; Habermas, 1987). One could say that they got "strained" as a result of the insight about their deceit and destroyed social capital (Agnew, 2006; Agnew, Leeper-Piquero, \& Cullen, 2009). ${ }^{4}$ At the same time, crisis responders nevertheless continue to depend on the recognition and resources of their environment for their ability to maintain (or improve) their personal standing in social life. However, the action of the crisis responders has another aim as well: that of preserving their work and family relationships intact (or improving them). The hidden actions are intimately coupled to the suspicion that adequate support may not be obtainable for the crisis responder's priorities from those around one, as the power to decide on its allocation now rests with the others; the crisis responder her- or himself is no longer able to influence the terms that govern her or his status in the relationship.

Rather than a result of a weakened social bond, as proposed by Sampson and Laub, the crisis responders' hidden actions may be better conceptualized as an outcome of shifting power relations, relegating them to a more subordinate position in which they find themselves increasingly dependent on the goodwill of others for their ability to maintain their relationships on previous terms. By concealing their problem, crisis

${ }^{4}$ One clarification seems important to make since I am making this remark about strain. The emotional state of strain mentioned above does not - from my point of view - contradict Sampson and Laubs theory. The reason for this is that "the state of strain" in this case (and the others) is a result of what Sampson and Laub would call attenuated informal social control. The relationship in question is threatened and attenuated when the actors in question realized that the consequences of the act makes it impossible for them to live up to others expectations and that they therefore cannot count on the acceptancy and the support that they are dependent on and so far have had. This insight is what is causing the strain (and not the reverse). Anyhow Sampson and Laubs theory should usefully be developed using the concepts and theories from the strain theory. responders adjust their image visible to others, so as to better meet the demands and expectations inherent in the relationship and secure continued acceptance. Yet, by doing so they also end up excluding something significant of themselves, "giving up major parts of [their] self in order to stay in the relationship" (Scheff, \& Retzinger, 2001: 25; Scheff, 1997: 77). In this situation, they are then forced to deal with their problems before a party they feel themselves inferior to and questioned by, while at the same time seeking this party's recognition; and it is precisely this fact that compels them to pursue possibilities for a hidden solution lest their future prospects of maintaining the relationship become jeopardized as a consequence of exposing oneself to others (Bowen, 1978: 478).

To sum up, we can thus observe that criminal solutions become topical for this category of white-collar offenders in situations where they find themselves deeply enmeshed in problems, remain locked in relations of subordination and dependency, and question their resources of social capital. For a crime to be carried out in these circumstances, to be sure, it is additionally required that the person in question perceives there to be a possibility for a hidden solution to begin with. In the following section, the role of supervision and monitoring in this scenario is therefore brought into focus.

\section{Hidden-Action Space and the Absence of Supervision and Monitoring}

It is a common understanding that economic crime is a phenomenon made possible by lax or lacking controls creating opportunities for wrongdoing (Bussman, \& Werle, 2006: 11; Vaughan, 1983). Existing research gives no reason to doubt such conclusions. In the case of the white-collar offenders in my sample, built-in opportunities for crime were of course included in very nature of their work, as employees in the banking and finance sector entrusted with not only administrative responsibilities but also the financial and technical tools to effectively manage those responsibilities. In addition, the individual offenders in my study had also acquired specialist knowledge and technical skills that made overseeing and monitoring their activities more complicated, and they all had been given relative freedom in attending to their duties. The instructions given them had generally been insufficient and the standard for administrative routines lax, with the day-to-day control and supervision frequently compromised or entirely lacking, either out of pure pragmatic considerations or owing to priorities centered on business expansion and profit margins.

As an example illustrating such circumstances, we may consider a case involving a broker working for a prestigious Swedish asset management firm with the responsibility for the firm's options business. During his time with the firm, the broker's status, responsibilities, and freedom of action had all steadily increased along with his ability to cope with the pressure put on its brokers to make deals, create profits, and expand trading activities. The firm's interest in the latter was as pronounced as its concern for controls and administrative efficiency and procedure was unapparent. Its attitude in this respect was expressed in no unclear terms when the broker's supervisor, in reviewing his work on new administrative tools for the options traders, told him to "Screw the paperwork! You are here to do business." The scant interest in management and procedures affected the quality of supervision and monitoring regarding the 
broker's activities, too. The issue was only compounded by the fact that the type of transactions under the broker's responsibility, as well known in the firm, was exceedingly complex in nature, with the result that the broker could soon begin to boast superior knowledge and understanding of the field in the company of his colleagues, superiors, clients, and auditors alike. While the latter had access to all records related to his transactions, they never fully understood the illegal nature of some of the deals made. This was an ignorance that the broker clearly felt he could live with in his immediate environment:

The audits were done by a couple of ladies ... They often came in and sat down to ask questions that they themselves had no real understanding about, and I gave them the answers. Obviously they could then never ask about [the client account I managed independently, on my own]... Like, whether this account was in good shape or not or whether it was actually losing money. That would have been hard to find out, too. I don't think they could have detected it, given their competence level.

Aided by the deficient controls in place at the firm, the broker was able to utilize his unique knowledge and experience to conduct transactions whose nature those around him could never fully understand. The broker then made use of this advantage in a criminal fashion following a failed deal made on behalf of one of the firm's biggest, most demanding, and valuable clients. The deal in question was but one of the many transactions the broker carried out for this client every day, having earned his trust and received his blessing to do so at his own discretion and with the instructions only to "Do the deals you think will be good." To that extent the broker had then made himself guilty of no wrongdoing thus far. In their magnitude, however, the losses from the bad bet were something out of the ordinary, amounting to slightly above one million US dollars, and thus the possibility that the broker might lose his client should this learn about the details was suddenly very real. For the client's trust that the broker enjoyed had been won only gradually; early on, the relationship had been marked by close scrutiny from the client's side, given his impression that the broker generally took liberties in his dealings with client accounts, taking unacceptable risks. The fact that the broker successfully passed the trial period and was subsequently given the responsibility for managing this particular client's account brought him much prestige among his colleagues as well as increasingly challenging work assignments. Another circumstance affecting his situation was that this responsibility was given him as a replacement of a colleague who, now reassigned, had caused this same client multimillion losses from a series of bad bets made on his behalf.

Despite the regular, almost daily contacts between them, the broker never managed to inform his client about the losses he now had caused to him, afraid of losing his position and the prestige he had earned through hard work at the firm. The elitist culture at his workplace, showing low tolerance for failure and expecting everyone to find their own solutions without undue outside assistance, only added to the broker's hesitation. Instead of approaching others openly about his failure, he then opted to try and hide his results, seeking to recoup the damage caused through new transactions that would help to permanently bury his losses in the company's books. At the time, he had no doubt that he would succeed in this, too - a confidence he shares with the above-reported bank manager and other crisis responders studied to date. Absence of controls and access to necessary technical skills allow a situation to arise in which crisis responders can feel themselves capable of gaining access to the "back regions" where there is room for hidden actions making possible a concealed solution based on means and resources entrusted to them (Engdahl, 2009). In consequence, the costs of this solution, involving the risk of being caught and the mental strain and exertion implementing it entails, are estimated to be relatively insignificant compared to the risks and the emotional ordeal that go with being open about the problem. In other words, crisis responders see themselves as having too much to lose by openness. Insofar as we can then say that crisis responders choose to commit their crime, this choice, as Sampson and Laub too are careful to point out, is to a high degree situationally conditioned and marked by fear of identity loss. This is an issue we will look at a little more closely next.

\section{Situated Choice under Threat of Identity Loss}

In the last few years, Sampson and Laub have shown increasing interest in the kind of choices and considerations entering into a decision to commit (or abstain from) crime. In particular, they have turned to the question of how changes in identity may encourage one to abandon the criminal way of life. According to Sampson and Laub, this may come about, for example, as a result of new responsibilities brought on by changes in family or employment status that may make criminal solutions lose their previous allure and appear as irrelevant or inconvenient instead. The circumstances surrounding the cases in my own study provide a mirror image of this precise possibility. In all of them, the problem at hand entailed a risk of being divested of responsibilities, authority, powers, and relationships holding high value for the individuals in question, achievements, moreover, on which their life's project and identity had been founded. In the case of the bank manager above, this involved the possibility of losing highly valued social relationships, whereas for the options broker it was the future of a highly valued professional career that was at stake. Thanks to the continuously greater independence and responsibility given him in his assignments, the broker had grown very much attached to his work. For him, work was "fun" and provided interesting challenges experienced as a "24/7-kind of thing" that his "whole life rotated around." Correspondingly, his salary too went up steadily and at a rapid pace during his time with the firm. In the other cases I studied, again, it was a question of individuals who were unable to extricate themselves from a lifestyle built around, or an identity bound up with, the possession of an expensive-to-maintain family estate, a status-yielding property, or expensive cars, or a gambling habit.

The specific purpose for which the money obtained through the criminal activity was to be spent thus varied from case to case. What was common in all cases, however, was the choice the offender made to prioritize her or his work or family role, lifestyle, or way of life over openness and the chance of losing social relationships that openness would have entailed. Consequently, the criminal activities in which these cases culminated might be best understood as a defensive response aimed at safeguarding a position or lifestyle that, having been attained through significant investment of time and effort, had now come under threat - as a way of protecting the integrity of the self, in other words. The problems the crisis responders face appear threatening since they entail the risk of bringing about a 
negative transformation in their (social) identity. In Sampson and Laub's own terminology, one could probably say that the crime of the crisis responders results from their exposure to problems of a scope and kind (i.e., nonshareable problems) that they are not in the habit of dealing with, while being emotionally too involved with their projects to be able to respond to this exposure in a candid and open fashion. They perceive themselves to have neither the mental readiness and social support required to address the problem in the full glare of publicity, nor the willingness to give up the life they are currently leading.

A fundamental feature in these cases is the deep preoccupation shown by crisis responders with an identity or a project that relegates the needs and desires of others to the background. Thereby the possibilities for successfully reversing course or falling back on something else are curtailed when the crisis responder's own resources to drive forward and complete such a project are depleted or found wanting. It is difficult for a crisis responder, however, to step outside of her- or himself to plan for alternatives. Instead, the situation becomes characterized by a certain risk-proneness, especially when the emotional involvement with one's project is particularly strong (Merton, 1968: 195; Alalehto, 2000; 2003). The relationships with others then becomes increasingly marked by a concentration on one's own needs and desires, which, especially when combined with poor supervision and control at workplace, feeds a tendency for the offender-to-be to morally cut her- or himself off from others (Scheff, 1997: 77; Scheff, \& Retzinger, 2001: 170). Thereby the obligations towards others implied in any stakes in conformity, which normally would act to inhibit crime, are weakened. With that, the appeal and even perceived necessity of criminal alternatives is further magnified simultaneously as the risks involved in not committing the crime become more obvious.

\section{Discussion and Conclusions}

Sampson and Laub's work on informal social control represents one of the more significant efforts in theory building in contemporary research about crime and criminality. Its influence has been considerable and continues to grow. In my research reported above, a pioneering effort was made to apply this theoretical framework to an analysis of data comprised of white-collar offenders only. In the main, it can be concluded that the theory has shown its usefulness in advancing our understanding of the mechanisms encouraging crime among the type of white-collar offenders in my sample. Support for the general thesis of the theory, that it is attenuated informal social control that initiates crime, is confirmed first and foremost by the finding that criminal activity, for this group at least, was triggered by the perpetrators' doubts regarding their own ability to mobilize the support from their social environment. The crimes were also facilitated by the absence of supervision and monitoring. Of particular significance here is the degree to which the deliberations accompanying the perception and attempted resolution of problems by the perpetrator remain emotionally charged. In their research on men who had successfully broken with their criminal past, Sampson and Laub (2003: 143) report having been "struck by the pride" that their study participants showed over their accomplishment. In the cases I studied, this emotional dimension was made equally manifest in the feelings of shame over one's shortcomings, anguish before the need to come out in the open and expose oneself to others, and fear at the prospect of losing one's status and social relationships. The intensity of these feelings was palpable enough to make further study of their role in the criminal process a priority (Giordano et al., 2007), with special focus on the significance of social support, interdependence, and crime as an attempt at preserving social relations intact. It is in this respect, too, that we can see a need for further clarification in aspects of Sampson and Laub's theory if we are to extend its explanatory power.

Sampson and Laub, to be sure, have put much emphasis on the interdependence of social ties, stressing that it is this quality that separates their approach from most others. To my knowledge, they have nonetheless failed to develop this theme further or explain whether, and how, this notion might in fact differ from terms such as weak, broken, and attenuated social bonds cultivated elsewhere in their work. Consequently, it remains unclear whether the theory is actually capable of dealing with the type of ambivalent relations found for instance in my own cases. But white-collar workers are also generally a part of, and dependent on, the established society in ways that vary significantly from the categories of criminals studied by Sampson and Laub. In my own study, this became particular evident in that the crisis responders' crime was ultimately aimed at preserving their existing social relationships, something that differs drastically from the case of those who, in the commission of their crime, show little concern for their social environment or who, by engaging in criminal activities, rather want to mark their distance from it. While in the latter two cases it indeed is a question, respectively, of weak and broken social bonds, the crime of the crisis responders, as seen from my examples, is instead shaped by a situation in which a power shift has left them in an increasingly subordinate position in their relationships, relationships moreover that maintain their strength while devolving into dependency. Interdependence is then a thing of the past, making it all the more difficult to gain a hearing for one's needs and desires. The feeling of having betrayed a trust placed in one in the form of responsibility and powers received, along with a failure to live up to the environment's expectations, with no one else but oneself to blame, seem to be other key determinants in the crisis responders' decision to hide their problems (rather than handling them out in the open or through outward aggression or vindictive action) (Kemper, 1978: 50ff.; Barbalet, 2001: 123ff).

Finally, it is also worth noting that the crisis responders included in my study almost without exception committed their first crime in adulthood. Although Sampson and Laub make the argument that even adult-onset offending can be explained within the framework of their theory, no more than preliminary empirical evidence has been offered to date to back up this claim (Eggleston, \& Laub, 2002). Overall, late onset of offending remains a little researched territory, and as of yet the proposals put forth regarding the notion of negative turning points that could then explain the phenomenon have not been met with serious discussion (Eggleston, \& Laub, 2002: 614; Zara, \& Farrington, 2010). While Sampson and Laub have shown that exposure to social support in adult age opens up positive turning points (which quite concretely mean cutting off the criminal social connections of the past and replacing them with an experience social support/control and an opportunity to forge a new identity) and may thus lead to desistance from future crime, the findings from the present study, in quite the opposite fash- 
ion, point to the possibility that the same may in fact initiate life-long law-abiding citizens into criminal behavior instead. As shown above, involvement in problems of hitherto unencountered type and dimensions, a threat to an identity resting on one's social roles and relationships, and doubts about the available social support make up the main characteristics of such negative turning points in an individual's life. If properly conceptualized, the notion of turning points as advanced by Sampson and Laub should then lend itself to an analyzing adult onset offending as well, providing new impetus for developing our understanding of this until now all-too-often overlooked and misconstrued phenomenon (Eggleston, \& Laub, 2002; Gomez-Smith, \& Piquero, 2005).

\section{References}

Agnew, R. (2006). Pressured into crime. An overview of general strain theory. Los Angeles, Calif: Roxbury.

Agnew, R., Leeper-Piquero, N., \& Cullen, F. T. (2009). General strain theory and white collar crime. In: Simpson, S. S. and Weisburd, D. (Eds.), The Criminology of White-Collar Crime (pp. 35-60). New York: Springer. doi:10.1007/978-0-387-09502-8_3

Alalehto, T. (2000). The act of economic crime: The logic of dirty business and normative restrictions in the Swedish restaurant industry. Journal of Scandinavian Studies in Criminology and Crime Prevention, 1, 156-177. doi:10.1080/140438500300076153

Alalehto, T. (2003). Economic Crime: Does Personality Matter? International Journal of Offender Therapy and Comparative Criminology, 47, 335-355. doi:10.1177/0306624X03047003007

Barbalet, J. M. (2001). Emotion, social theory, and social structure: A macrosociological approach. Cambridge, UK: Cambridge University Press

Bernard, T, Snipes, B., \& Gerould, A. (2010). Vold's Theoretical Criminology (6th ed.) New York: Oxford University Press.

Bottoms, A. (2006). Desistance, social bonds, and human agency: A theoretical exploration. In P.-O. Wikström and R. J. Sampson (Eds.). The Explanation of Crime: Context, Mechanisms, and Development (pp. 243-290). Cambridge, UK: Cambridge University Press.

Bowen, M. (1978). Family therapy in clinical practice. New York: Jason Aronson.

Bussman, K-D., \& Werle, M. (2006). Addressing crime in companies: First findings from a global survey of economic crime. British Journal of Criminology, 46, 1128-1144. doi:10.1093/bjc/azl072

Coleman, J. S. (1990). Foundations of social theory. Cambridge: Harvard University Press.

Cressey, D. R. (1953). Other people's Money: A study of the social psychology of embezzlement. Glencoe, IL: Free Press.

Cullen, F., Wright, J. P., \& Blevins, K. R. (Eds.) (2006). Taking Stock: The Status of Criminological Theory. New Brunswick, NJ: Transaction Publishers.

Eggleston, E. P., \& Laub, J. H. (2002). The onset of adult offending: A neglected dimension of the criminal career. Journal of Criminal Justice, 30, 603-622. doi:10.1016/S0047-2352(02)00193-9

Engdahl, O. (2008). The Role of Money in Economic Crime, British Journal of Criminology, 48, 154-170. doi:10.1093/bjc/azm075

Engdahl, O. (2009) Barriers and back regions as opportunity structures for white-collar crime. Deviant behavior, 30, 115-143. doi: 10.1080/01639620802050148

Ezell, M. E. (2007). The effect of criminal history variables on the process of desistance in adulthood among serious youthful offenders. Journal of Contemporary Criminal Justice, 23, 28-49. doi: $10.1177 / 1043986206298943$

Ezell, M. E., \& Cohen, L. E. (2005). Desisting from crime: Continuity and change in long-term crime patterns of serious chronic offenders.
Oxford: Oxford University Press

Flyvbjerg, B. (2006). Five misunderstandings about case-study research. Qualitative Inquiry, 12, 219-245. doi: $10.1177 / 1077800405284363$

Giordano, P. C., Cernkovich, S. A., \& Rudolph, J. L. (2002). Gender, crime, and desistance: toward a theory of cognitive transformation. The American Journal of Sociology, 107, 990-1064. doi: $10.1086 / 343191$

Giodano, P. C., Schroeder, R. D., \& Cernkovich, S. A. (2007). Emotions and crime over the life course: A Neo-meadian perspective on criminal continuity and change. American Journal of Sociology, 112, 1603-1661. doi:10.1086/512710

Gomez-Smith, Z., \& Piquero, A. R. (2005). An examination of adult onset offending. Journal of Criminal Justice, 33, 515-525. doi:10.1016/j.jcrimjus.2005.08.001

Habermas, J. (1987). The theory of communicative action. Vol. 2: Lifeworld and system: A critique of functionalist reason. Boston, MA: Bacon Press.

Honigmann, J. J. (1982). Sampling in ethnographic fieldwork. In: Burgess, R. G. (Eds.), Field Research: A Sourcebook and Field Manual. London: Allen and Unwin.

Horney, J., Osgood, W. D., \& Marshall, I. H. (1995). Criminal careers in the short-term intra-individual variability in crime and its relation to local life circumstances. American Sociological Review, 60, 655-673. doi: $10.2307 / 2096316$

Kemper, T. D. (1978). A social interactional theory of emotions. New York: Wiley.

Laub, J. H. \& Sampson, R. J. (1993). Turning points in the life course: Why change matters to the study of crime. Criminology, 31, 301-325. doi:10.1111/j.1745-9125.1993.tb01132.x

Laub, J. H., \& Sampson, R. J. (2003). Shared beginnings, divergent lives: Delinquent boys to age 70. Cambridge, MA: Harvard University Press.

Laub, J. H., Nagin, D. S., \& Sampson, R. J. (1998). Trajectories of change in criminal offending: Good marriages and the desistance process. American Sociological Review, 63, 225-238. doi: $10.2307 / 2657324$

Laub, J. H., Sampson, R. J., \& Sweeten, G. A. (2006). Assessing Sampson and Laub's life-course theory of crime. In F. T. Cullen, J. P. Wright and K. R. Blevins (Eds.), Taking Stock: The Status of Criminological Theory (pp. 313-333). New Brunswick, NJ: Transaction Publishers.

Leeper-Piquero, N., \& Benson, M. L. (2004). White-collar crime and criminal careers: Specifying a trajectory of punctuated situational offending. Journal of Contemporary Criminal Justice, 20, 148-165. doi: $10.1177 / 1043986204263770$

Leeper-Piquero, N., \& Weisburd, D. (2009). Developmental trajectories. In Simpson, S. S. and Weisburd, D. (Eds.), The Criminology of White-Collar Crime (pp. 153-171). New York: Springer.

Lilly, R. J., Cullen, F. T., \& Ball, R. A. (2007). Criminological theory: context and consequences (4th Ed.) London: Sage.

Mackenzie, D. L., Browning, K., Skroban, S. B., \& Smith, D. A. (1999). The impact of probation on the criminal activities of offenders. Journal of Research in Crime and Delinquency, 36, 423-453. doi:10.1177/0022427899036004004

Mackenzie, D. L., \& Li, S. D. (2002). The impact of formal and informal social controls on the criminal activities of probationers. Journal of Research in Crime and Delinquency, 39, 243-276. doi:10.1177/002242780203900301

Merton, R. K. (1968). Social theory and social structure (revised ed.) Glencoe, IL: Free Press.

Paternoster, R., \& Bachman, R. (Eds.) (2001). Explaining criminals and crime: essays in contemporary criminological theory. Oxford, UK: Oxford University Press.

Piquero, A. R., \& Mazerolle, P. (Eds.) (2001) Life-course criminology: Contemporary and classic readings. London: Wadsworth Thomson Learning.

Sampson, R. J., \& Laub, J. H. (1990). Crime and deviance over the life course: The salience of adult social bonds. American Sociological 
Review, 55, 609-627. doi:10.2307/2095859

Sampson, R. J., \& Laub, J. H. (1993). Crime in the making: Pathways and turning points through life. Cambridge, MA: Harvard University Press.

Sampson, R. J., \& Laub, J. H. (2003). Life-course desisters? Trajectories of crime among delinquent boys followed to age 70 . Criminology, 41, 555-592.doi:10.1111/j.1745-9125.2003.tb00997.x

Sampson, R. J. \& Laub, J. H. (2005a). A life-course view of the development of crime. Annals of the American Academy of Political and Social Science, 62, 12-45. doi:10.1177/0002716205280075

Sampson, R. J. \& Laub, J. H. (2005b). A general age-graded theory of crime: lessons learned and the future of life-course criminology. In D. P. Farrington (Eds.). Integrated Developmental and Life-Course Theories of Offending (pp. 165-181). Advances in Criminological Theory, Vol. 14. Piscataway, NJ: Transaction Publishers.

Scheff, T. J. (1997). Emotions, the Social Bond, and Human Reality: Part/Whole Analysis. Cambridge, UK: Cambridge University Press. doi:10.1017/CBO9780511549496

Scheff, T. J. \& Retzinger, S. M. (2001). Emotions and Violence: Shame and Rage in Destructive Conflicts. Lexington, MA: Lexington Books.

Simons, R. L., Stewart, E., Gordon, L. C., Conger, R. D., \& Elder, Jr., G. H. (2002). A test of life-course explanations for stability and change in antisocial behavior from adolescense to young adulthood. Criminology, 40, 401-434. doi:10.1111/j.1745-9125.2002.tb00961.x

Thompson, M. \& Petrovic, M. (2009). Gendered transitions: Withinperson changes in employment, family, and illicit drug use. Journal of Research in Crime and Delinquency, 46, 377-408. doi: $10.1177 / 0022427809335172$

Uggen, C. (2000). Work as a turning point in the life course of criminals. American Sociological Review, 65, 529-546. doi: $10.2307 / 2657381$

Vaughan, D. (1983). Controlling unlawful organizational behavior.
Social structure and corporate misconduct. Chicago and London The University of Chicago Press.

Waring, E., Weisburd, D., \& Chayet, E. (1995). White-collar crime and anomie. In Adler, F. and Laufer, W. S. (Eds.), The Legacy of Anomie Theory (pp. 207-225). New Brunswick, NJ: Transaction Publishers.

Warr, M. (1998). Life-course transitions and desistance from crime. Criminology, 36, 183-213. doi:10.1111/j.1745-9125.1998.tb01246.x

Weisburd, D., Waring, E., \& Chayet, E. (2001). White-collar crime and criminal careers. New York: Cambridge University Press. doi:10.1017/CBO9780511499524

Weisburd, D., Waring, E., \& Leeper-Piquero, N. (2008). Getting beyond the moral drama of crime: What we learn from studying white-collar criminal careers. In J. Minkes and L. Minkes (Eds.). Corporate and White-Collar Crime (pp. 179-201). London: Sage

Williams, J. W. (2004). Governmentability matters. The private policing of economic crime and the challenge of democratic governance. Policing \& Society, 15, 187-211. doi:10.1080/10439460500071671

Williams, J. W. (2005). Reflections on the private versus public policing of economic crime. British Journal of Criminology, 45, 316-339. doi:10.1093/bjc/azh083

Williams III, F. P., \& McShane, M. D. (2009). Criminological theory (5th ed.). Upper Saddle River, NJ: Pearson/Prentice Hall.

Yin, R. K. (1989). Case study research: Design and methods. Beverly Hills, CA: Sage.

Zara, G., \& Farrington, D. P. (2010). A longitudinal analysis of early risk factors for adult-onset offending: What predicts a delayed criminal career? Criminal Behavior and Mental Health, 20, 257-273. doi:10.1002/cbm.763

Zeitz, D. (1981). Women who embezzle and defraud: A study of convicted felons. New York: Praeger. 